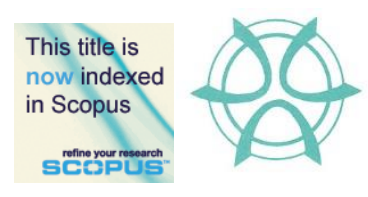

PLANNING MALAYSIA:

Journal of the Malaysian Institute of Planners

Volume XI (2013), Page 41 - 58

\title{
AWARENESS BY KUALA LUMPUR CITY HALL STAFFS FOR SUCCESSFUL IMPLEMENTATION OF CRIME PREVENTION THROUGH ENVIRONMENTAL DESIGN (CPTED)
}

\author{
Shuhana Shamsuddin ${ }^{1} \&$ Natasha Azim Hussin ${ }^{2}$ \\ ${ }^{1}$ Razak School of UTM in Engineering and Advance Technology \\ ${ }^{2}$ Faculty of Built Environment \\ UNIVERSITI TEKNOLOGI MALAYSIA
}

\begin{abstract}
A city that is free from all forms of crime and criminal threats will able to create a community that has quality human capital. Both crimes and the fear of crime have a significant impact on the quality of life. A safe city is a key to the success of community development, urban development and nation building. Rising of crime index for past six years in Kuala Lumpur is questionable whether CPTED has been successfully carried out by the KLCH in creating a safe urban environment for people to live in. Urban development Plans should make safety primary criteria in making the city successful and livable. This research aims to investigate the awareness level of Kuala Lumpur City Hall $(\mathrm{KLCH})$ implementer in implementing the Crime Prevention through Environmental Design (CPTED) which was introduced in 2004 by the Malaysian Government. A mixed method research approach was adopted employing a questionnaire survey and in depth interview with a sample of officers and technician of KLCH whose scope of work includes the implementation of CPTED. The findings suggest that the existing level of awareness is still low with the lack of awareness on CPTED due to the limited knowledge and poor understanding of CPTED concept and implementation. However, it was also found that the implementers of $\mathrm{KLCH}$ are beginning to develop an awareness of the importance of safety urban environment and are beginning to consider the capability of the built environment in reducing both, the fear of crime and the actual crime from happening. Successful CPTED implementation will be a meaningful contribution towards the creation of a safe
\end{abstract}

${ }^{1}$ Associate Professor at Razak School of UTM in Engineering and Advanced Technology, Universiti

Teknologi Malaysia. Email: shuhana@ic.utm.my 
Shuhana Shamsuddin \& Natasha Azim Hussin

Awareness by Kuala Lumpur City Hall Staffs for Successful Implementation of Crime Prevention through Environmental Design (CPTED)

city that is livable for the urban community in Kuala Lumpur therefore helping to improve their quality of life.

\section{Keywords: CPTED}

\section{INTRODUCTION}

Awareness of Kuala Lumpur City Hall's implementers is the most important factor for any policy implementation. It has not been explained so much in other previous study and research on successful policy implementation. Without KLCH implementer's awareness on current policies and trend, it is impossible for them to gain the knowledge of the policy, understanding how to implement it and a commitment for the implementation and develop a skill in implementing the policy is required. Crime Prevention through Environmental Design (CPTED) is partially one of the Safe City crime prevention strategies that have been adopted since 2004 by the Malaysian Government. Rising of crime index for past six years in Kuala Lumpur is questionable whether CPTED has been successfully carried out by the KLCH in creating a safe urban environment for people to live in. Thus this study takes initiatives to investigate the level of CPTED awareness by the KLCH implementers. The study was conducted among the professionals and technical staffs from selected technical departments that involved in the Kuala Lumpur development process.

The crime rates in Malaysia getting worsen since the year of 1991 when it increased more than $300 \%$. The seriousness of this problem can be concluded up in the year 2007, where the sum of crime rate statistics is about 588 murder cases and 3,177 rape cases which equivalence to more than one person was murdered (1.6 per day) and more than eight women were raped every day (8.7 per day) (Amar Singh Sidhu, 2005). Increase of the crime rate never stops at any point especially the violent crime that increased by $85 \%$ from year 2003 to 2006. For the first five months of the year 2007 the crime rate in Malaysia increased by $8.7 \%$ and that year become the worst year due to the increasing crime index of 156, 315 cases in 2003 up to 224,298 cases in 2007 which the rise is $45 \%$ over past four years (Amar Singh Sidhu, 2005). CPTED implementation that started in 2004 did not yield a proper result. In 2004, the crime rate in Kuala Lumpur especially snatches thefts increased and contributed to $18 \%$ of the crime index (Chor Chee Heung, 2010). The increasing crime rates continue from year to year and the decline of the crime rates in 2010 was due to the initiative taken by the government by making the crime prevention as a NKRA in Government Transformation Program (GTP) 2010. Increasing of 
the crime rate for the past six years in Kuala Lumpur has been questioned, whether the CPTED implementation by the $\mathrm{KLCH}$ was successfully implemented in KL. This research assumes that by increasing the implementer's awareness, CPTED implementation will be more successful in Kuala Lumpur. Further sections of the paper then, examine the level of awareness of implementers in KLCH and the level of CPTED implemented by them. The paper concludes that to achieve a successful of CPTED implementation, awareness is one of the factors that need to be looked into.

\section{CRIME IN MALAYSIA}

Crime and fear of crime are a major urban stress and crime problems are social issues that affect thousands of people's lives each year (Massoomeh Hedayati Marzbali et al, 2012). Malaysia is one of the most rapidly developing countries in Southeast Asia (Wong, T.C et al., 2006) and one of the challenges faced by the nation is the increase in crime rate. The social aspect is one of the key elements that contribute to the sustainable development of other aspects of the environment and the economy (Halimaton Saadiah Hashim, 2011). Figure 1 would give a better and clear picture of the rising crime rate in Malaysia. This has caused real fear amongst the public at large, most prominently amongst women and children whose lives are most directly affected.

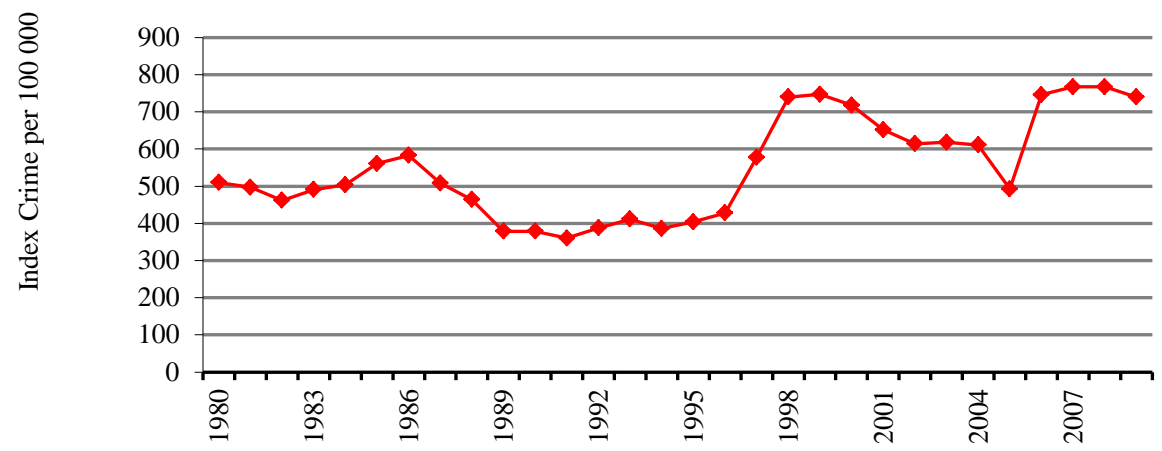

Figure 1: Crime Index In Malaysia from 1980 - 2010

Sources : Royal Malaysia Police 2011

The seriousness in the increasing crime rate has caused a drastic action by the government by focusing on the crime prevention. Crime prevention has become as a National Key Result Area (NKRA) major goal of Malaysia Government in providing a better and safe environment for people to live. 
Shuhana Shamsuddin \& Natasha Azim Hussin

Awareness by Kuala Lumpur City Hall Staffs for Successful Implementation of Crime Prevention through Environmental Design (CPTED)

Malaysia government is not exempted from this matter where over RM37 billion for the year 2010 and RM35 billion for the year of 2011 were spent for the crime problem (Annual Report Government Transformation Programme Roadmap, 2011). An immediate effort was taken to combat this problem through supervision by police in the selected hot spot area which was also known as a Target Hardening strategy. Currently less than $8 \%$ of the Royal Malaysian Police force is directly fighting crime (Annual Report Government Transformation Programme Roadmap, 2011). The police alone cannot provide all the solutions for crime prevention, householders and communities must learn to help themselves and regain control over their neighbourhoods through forming groups such as Neighbourhood Watch. The physical built environment also helps in preventing crime from happening. This has been practiced by many other countries around the world. A quality design of the urban built environment is needed to prevent crime and a good community cooperation is needed to create a better living environment become a strategic strategy in order to making the cities in Malaysia a safe city.

\section{CRIME PREVENTION THROUGH ENVIRONMENTAL DESIGN (CPTED) AND ITS IMPLEMENTATION IN MALAYSIA}

Crime and environment and the spatial patterning of crime has become a hot debate and the big discussion started way back in 1920s (Shaw and McKay). The concept of CPTED is an idea of how the design of physical of built environment plays an important role in the prevention of criminal acts by their behavior and can lead to a reduction in the fear of crime and the incident of crime which can improve the quality of life. The Opportunity Theory of Crime Prevention was developed during the 1970s and was initiated and expanded by researchers from UK Home Office Research Unit (Massoomeh Hedayati Marzbali et al., 2011). The goal is to reduce the opportunities for crime to occur by creating a defensive environment with approaches from both the physical and the psychological aspects as the same time. This reduction is achieved by employing physical design features that discourage crime, while at the same time encouraging the legitimate use the environment. National Crime Prevention Institute explained that a CPTED program is based on the premise that the proper design and effective use of the built environment which can lead to a reduction in the fear and incidence of crime, as well as an improvement in the quality of life (Rebecca Lynn Wenzelm. 2007) for both the psychological aspects of human nature and the role of the external physical environment on human behaviour. On the external physical environment aspect, he suggested that the urban design, including the design of streets, parks, terminals and 
super highways, could prevent crimes from occurring by reducing the "opportunities" to the criminals. CPTED is an idea using the physical environment as protection against attack (Robert A. Gardner, 1981). The essence of CPTED in creating a defensive environment is approached from both the physical and the psychological aspects. To ensure the effectiveness of CPTED, it should be applied both to external and internal physical environments, and to the environments of the place and the offender, respectively (Matthew B. Robinson, 1996).

The concept of the CPTED program are a manipulation of the physical environment in producing behavioural effects that will reduce the incidence and fear of crime which will help in improving the quality of life (Crowe, Tim. (2000), Ronald V. Clarke (1998) \& Robert A. Gardner, 1981). Robinson Taylor and Harrell (1996) describe CPTED as "focuses on the settings in which crimes occur and on techniques for reducing vulnerability of the settings" because its central premise is that crime can be facilitated or inhibited by features of the physical environment. Agreed by Crowe (2000), where CPTED as a proper design and effective use of the built environment can lead to a reduction in the fear of crime and the incidence of crime, and to the improvement in the quality of life. A proactive design approach used by urban planners is to manage settings for incidences of crime and the fear of crime in building environments which are buildings, street, open space and parks. CPTED approach is perceived to have a stronger effect in influencing fear towards crime. This is due to the fact that the CPTED approach involves constant elements that may be modified through planning and design. This has been proven through several researches that discovered the physical environment can open up opportunities for crimes to be committed. CPTED as including physical layout, housing typologies as well as neighbourhood outlook and appearance are the main criteria that become the focus for the occurrence of crime. This aspect is believed to have a correlation with certain physical configurations which may generate more comfortable surroundings in which people can communicate and act in a better and easier way.

The first program of crime prevention in Malaysia was the Safe City launched in 2004 which consist of 23 steps for the first action and 15 steps on the second movement. The earlier Safe City action was using CPTED strategies as crime prevention. However, the crime rate obtained from the RMP by the researcher did not show positive results compared with the years of CPTED implementation. It is important to ensure the success of CPTED implementation in providing a better quality of life to the people in Kuala Lumpur.

Several methods have been introduced to achieve the effective physical environment in the implementation of the Safe City. A safe city can be achieved 
Shuhana Shamsuddin \& Natasha Azim Hussin

Awareness by Kuala Lumpur City Hall Staffs for Successful Implementation of Crime Prevention through Environmental Design (CPTED)

by a designing the environment with the safety as a major focus and providing a quality of planning layout. Environmental Design Initiatives is a strategy that was implemented by the JPBD to create a physical design environment that helps in preventing and combating criminal activities from occurring. In Malaysia, the national budget for 2010 was presented by the Prime Minister YAB Dato' Sri Mohammad Najib Tun Razak, which an amount of RM3.7 billion was allocated for the crime prevention program. However, the amount allocated is only focused on the provision to enhance the efficiency of security personnel, including providing modern and sophisticated equipment. It aims to achieve the crime reduction target of 5 per cent at the end of 2010. The CPTED Implementation Guide was introduced in March 2011. It is a reference document for all relevant decision makers, planners, managers and designers. This document contains a summary of concepts, general guidelines and userfriendly checklists. It outlines the basic requirements for the design and management of the built environment of the community, city, and town for a safer and more secured environment. Implementation of CPTED is not only used for new development but also implemented in the existing development to create safer cities in Malaysia. Architects, designers and town planners have been concerned with crime problems in urban centres and residential areas and their effects on the human well-being. Therefore, the role of $\mathrm{KLCH}$ implementers including the planners, architect and other design professionals should take into consideration the surrounding environment in order to reduce or enhance crime rates. In this research, the implementation of CPTED by the $\mathrm{KLCH}$ is reviewed by accessing the implementers' awareness on "what is CPTED" and "when" they started to implement the policy. The importance of the CPTED implementation by KLCH implementers will contribute to a better and safe built environment which will lead towards the reduction of crime happen in the urban area.

\section{Policy Implementation and Successful Implementation}

Implementation is both an outcome and a process. Implementation is connected to specific policies as particular to specific problems in the society and it is a process involved individuals with different background, organizations, procedures and techniques working together to ensure the policies effect the program goals. According to Van Meter and Van Horn, the process includes one time and continuing efforts to achieve the mandated by policy decision. Policy implementation is what develops between the establishments of an apparent intention on the part of government doing something or stop doing something and the ultimate impact of world of actions. 
Successful implementation, defined by Matland, requires compliance with statues' directives and goals; achievement of specific success indicators; improvement of political climate that surround the program. A successful policy implementation occurs when a policy is carried out in full and external circumstances are not favourable and the policy produces the intended results or outcomes. Implementation failure, like implementation success, is therefore a highly contested concept. Its description depends on the intentions, expectations and values of those involved in policy implementation. Meanwhile in, Elmore defined failures of implementation is lapses of planning, specification and control. Wildavsky explained that policy failure is resulted from nonimplementation or from unsuccessful implementations which occur when there is a division between formulating a policy and implementing it. Persistent implementation failure is often the result of applying a mistaken theory of change. Failure of implementation has largely been treated as a minor flaw, a treatable and transitory mistake. The criteria for successful or failed implementation are then not focused on the degree of match or mismatch between formal intentions of the policy and actions of the implementers, or on the deviant behaviour of implementers. Instead, they measure the programme in terms of the positive gains. These gains might be due to intended or unintended outcomes. It is mostly done by researchers to explain the existence of "implementation gap". The existence of this gap can thwart the implementation of the policy. This has been a concern to the social scientist, but not to the policy makers. It is important to understand the nature of policy implementation because international experience shows that policies, once adopted, are not always implemented as envisioned and do not necessarily achieve intended results.

According to Pressman and Wildavsky (1984) implementation is complicated by the fact it involves multiple actors in multiple organizations, and within an organization and different staff from different departments is also involved. It can be concluded as a process with stages performs with the implements for a specific target group with an output is either intended or unintended. Agreed with Franklin and Ripley, they explained that the actors holding, diffuse, completing goals and work within a context of a complex mix of government programs that require participation from numerous layers, units and who are affected with the policy. Either people or action both are related in the implementation process and have an impact on the specific task given. Ball describes that policy, by its nature, is not value neutral but it is "a matter of authoritative allocation of values" and he argues that policies cannot be separated from the interests, conflict and domination or justice. He considered the human as a major factor because it emphasizes the powerful authority in the problem solving ability of the people. This theory analyses various 
Shuhana Shamsuddin \& Natasha Azim Hussin

Awareness by Kuala Lumpur City Hall Staffs for Successful Implementation of Crime Prevention through

Environmental Design (CPTED)

implementation games which hinder policy implementation and propose a specific ways to overcome those obstacles. Implementation involved so many factors and the implementers are very important to be discussed to ensure the successful implementation of a policy.

The "people issues" may be endemic to any policy implementation and it's an issue to be discussed and it is crucial to realize as a condition for successful CPTED implementation by KLCH. The issue with the implementing agency has been focused for decades. The accurate characteristic of implementing agency needs to be considered in developing the program for the implementation. Organization and implementers are the core factor in transforming the policy into action and its importance cannot be disputed. Meter and Horn described the three elements of the implementers' response may affect their ability and willingness to carry out the policy are (1) their recognition which consisted of comprehension and understanding of the policy, (2) direction of their response,(3) and intensity of that response. All elements mentioned will lead to the successful implementation and are linked to each other in accord to their model. The characteristics of implementing agencies and the implementers may have an effect on the effective implementation. Policymakers and program implementers also often have limited understanding of how broader policies might help overcome service delivery obstacles.

\section{RESEARCH METHODOLOGY}

The research employed a case study method using a mixed method approach in investigating the level of awareness of the CPTED program among the policy implementers in the local authority. This study was conducted in Kuala Lumpur City Hall $(\mathrm{KLCH})$ which is the largest local authority in Malaysia. There are three types of data collection techniques administrated. First, a questionnaire survey method that is followed by In Depth Interview. Another method used in this study is the content analysis of the relevant official documents.

The questionnaire survey technique is consistent with Bell (1996) where he explained that the most obvious way to measure the level of thinking, behavior, emotions and human behavior is to ask questions about what they feel, think, do and done. It was also agreed by Shuhana (1997) in which according to her, Canter (1977) has stated that the easiest way to explore human responses and reactions in a place is to ask questions so they can explain it. In this research, the questionnaire was designed using a Likert scale and a Thurstone scale as a measurement. Meanwhile the in depth interview was used 
because the information received from an individual is very valuable and highly valued. The main objective in this data collection process is to see the awareness of the top management on the implementer's awareness in implementing the CPTED. In this study, three top management officers that function as decision maker were interviewed using a semi-structured interview schedule. The in depth interview method was conducted in its natural setting where the researcher seeks to listen to participants and build a picture based on their experiences and perceptions. In other words qualitative study allows for in depth analysis of comments and perceptions of individual involved in implementing the CPTED.

A total of 11 out of 25 departments which involved in KL development were selected to be involved in the survey. The departments are; (1) Economic Planning and Development Coordination Department, (2) Master plan Department, (3) Urban Planning Department, (4) Public Works, (5) Urban Transportation Department, (6) Drainage \& River Management Department, (7) Architect Department, (8) Quantity Surveying Department, (9) Mechanical Engineering Department, (10) Urban Design \& Building Department and (11) Landscaping and Urban Cleaning Control Department. The choice of selecting the respondents in each department is based on their technical background and their involvement with KL developments. They are divided into two groups. The first group is Top Level Management in KLCH that comprised of three Head of Departments and function as a decision maker in the organization and involved directly with the CPTED policy and implementation. Meanwhile the second group is Professional and Implementers group. This group consists of officers and staffs whose starting grade is 48 to grade 11. All the implementers mentioned above are either the officer at top management level or the technicians that are fully involved with the development of Kuala Lumpur. Two main criteria were listed to decide on the CPTED implementers to be the surveys which are (1) department function and scope of work in development, (2) staffs' function and scope of work in development. Those $\mathrm{KLCH}$ staff whose duties are as a decision maker and implementers will be automatically identified as a potential respondent. A staff name list, grade designation and employment are carefully created from the total of 11 departments. The result calculated is an 867 staffs whose roles are as CPTED implementers in KLCH. The sampling technique is based on purposive sampling method. This technique is chosen based on certain criteria of selected respondents in KLCH and this sampling technique should be used when the researcher has a judgment with a specific purpose in mind and use it in selecting the initial samples. The sampling technique used is a purposive sampling method. This technique is chosen based on certain criteria of selected respondents in KLCH and this sampling technique should be used when the researcher has a judgment with a 
Shuhana Shamsuddin \& Natasha Azim Hussin

Awareness by Kuala Lumpur City Hall Staffs for Successful Implementation of Crime Prevention through Environmental Design (CPTED)

specific purpose in mind and use it in selecting the initial samples. A sample size of 361 out of this total of 867 respondents that was identified as CPTED implementers was then obtained as respondents.

A mixed method approach was employed to analyse the data with the quantitative approach used as a predominant method due to statistical data being used as a measurement to achieve the aim of this study. The technique was selected because it is a numeric and data often associated with accuracy. A few tests were used based on the aims and types of data collected. The quantitative analysis was conducted using the statistical test such as descriptive analysis and inferential statistics. Meanwhile Pearson Chi Square, Cramer V, Spearman Correlation analysis was selected to seek for awareness level and Multi Respond test was used to determine the level of CPTED.

\section{FINDINGS}

\section{Respondent's profile}

A total of 867 respondents in this study was working in $\mathrm{KLCH}$ and involved in urban development of Kuala Lumpur. To support the obtained quantitative data, three staffs from the top level were interviewed in collecting the qualitative data. The background of survey respondents included their working position, status, working group, grade, gender, age, educational background, working experience and scope of work. Fig.3 shows the percentage of staff's position in $\mathrm{KLCH}$ organization and the importance of their roles i.e. technician $29 \%$, Assistant Architect 20\% and Technical Assistant 14\% which dominated the total of implementers in KLCH. It is very important to seek their awareness in CPTED understanding and implementation because they are the main group of implementers for this policy. From the findings, the management can determine which group to focus on training of CPTED implementation. 
PLANNING MALAYSIA:

Journal of the Malaysia Institute of Planners (2013)
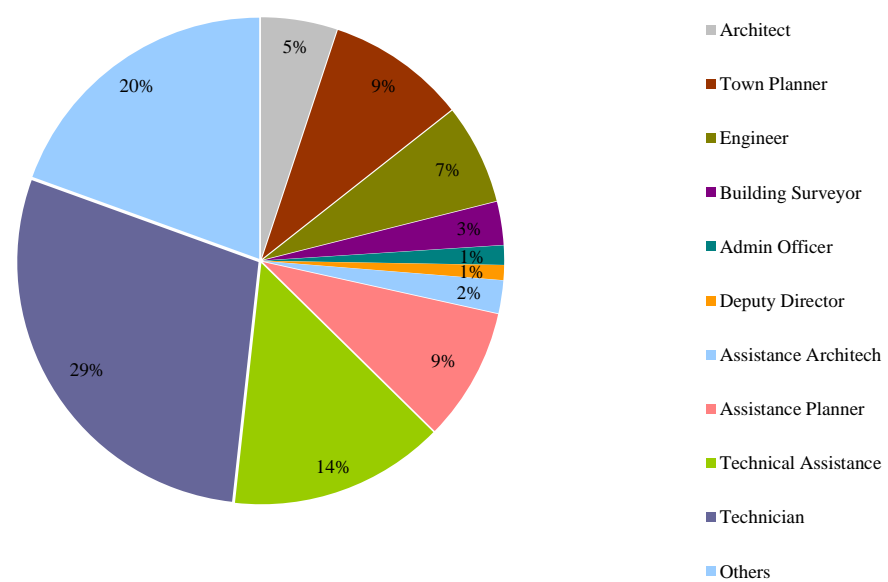

Figure 3. Implementers Position in $\mathrm{KLCH}$

Source : Field Work, 2012

The second part of the demographics survey is more focusing on the education background, working experience and current scope of works. The working experience in the current scope of work it will reflect on the staff skills and ability in the CPTED implementation. This study discovers that most of the implementers are well-educated with $33.9 \%$ are degree holder which accumulates 108 people. Staffs with diploma and certificate holder were $26.6 \%$ (85 people) and $22.9 \%(\mathrm{~N}=73)$ as shown in Fig.4. Implementers with technical background play a major role in ensuring the CPTED policy implemented accordingly for urban development in Kuala Lumpur.

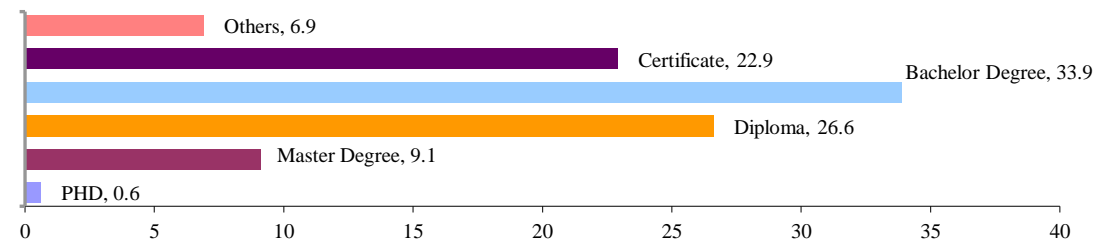

Figure 4.Implementers Educational Background in KLCH

Sources : Field Work, 2012

There are two groups of respondents, which are the technical and nontechnical staff. Most of the respondents that involved in this survey have worked in KLCH more than 20 years that cover the $30 \%(\mathrm{~N}=96)$ from the total 
Shuhana Shamsuddin \& Natasha Azim Hussin

Awareness by Kuala Lumpur City Hall Staffs for Successful Implementation of Crime Prevention through Environmental Design (CPTED)

respondents. It is followed by those that have been working in $\mathrm{KLCH}$ for $1-5$ years with $27.8 \%(\mathrm{~N}=89)$. But yet those experience staff still dominated the function as implementers with $18.8 \%$ for $6-10$ years, $11.6 \%$ for $11-15$ years and $11.9 \%$ for $16-20$ years working experience. The technical scope of work totally dominated by the male with $65.9 \%(\mathrm{~N}=211)$ compared with female which only $34.1 \%(\mathrm{~N}=109)$. Moving on, one of the last questions queried their scope of work. $17.8 \%$ of the respondents were involved in building inspection scope of work. The most important stage in implementing the CPTED is in the evaluation of development proposals in which 80 people. $25.4 \%$ staffs were involved in this stage. $29.7 \%$ were involved in project implementation and others were involved as a policy and decision maker. It was assumed that respondents were majority of technical and educated background with long experience working in KLCH and were the implementers of CPTED policy for urban development in Kuala Lumpur.

\section{Level of awareness}

Awareness of the actual year of the Safe City and CPTED implementation is less than $20 \%$ with only $14.1 \%(\mathrm{~N}=36)$ from 255 staff and only $15.6 \%(\mathrm{~N}=29)$ from186 staff aware of the actual year of the Safe City Program and CPTED implementation by the government and KLCH which both program has started simultaneously in year 2004 (Fig. 5).

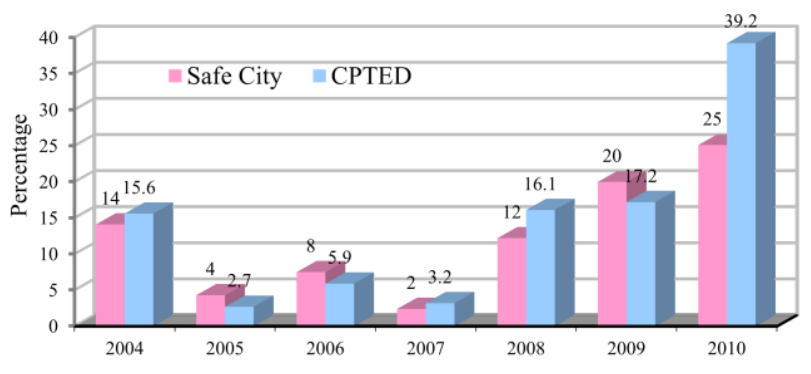

Figure 5.Implementation of Safe City and CPTED by KLCH

A Chi-Square test was tested and discovered that both awareness of year of Safe City Implementation and year of CPTED implementation was significantly related, $x^{2}=77.555^{\mathrm{a}}, \mathrm{p}<.05, \quad \mathrm{p}=.000$. The finding shows that the value of $\mathrm{p}<.05$, with more than half of the implementers with $79.2 \%$ answering 2010 as a year of Safe City and CPTED implementation followed by 2004 with 63\% and 2009 with $44.7 \%$. Meanwhile the Cramer V measures the degree of the relationship and found that the awareness of year of Safe City 
implementation had a less significant relationship $(\mathrm{V}=0.525)$ to the year of CPTED implementation.

On the second finding of awareness factor, another two questions were asked in order to seek the awareness of the CPTED implementation by the $\mathrm{KLCH}$. Both questions are referring to the same answers expected by the researcher and the answer to both questions should be of no significant difference. The finding on this matter discovered that a huge gap as shown in Fig.6 for both similar questions. The differences either for "Yes" or "No" answer for both similar questions are $23.1 \%$ and $14.1 \%$ (Fig 6).

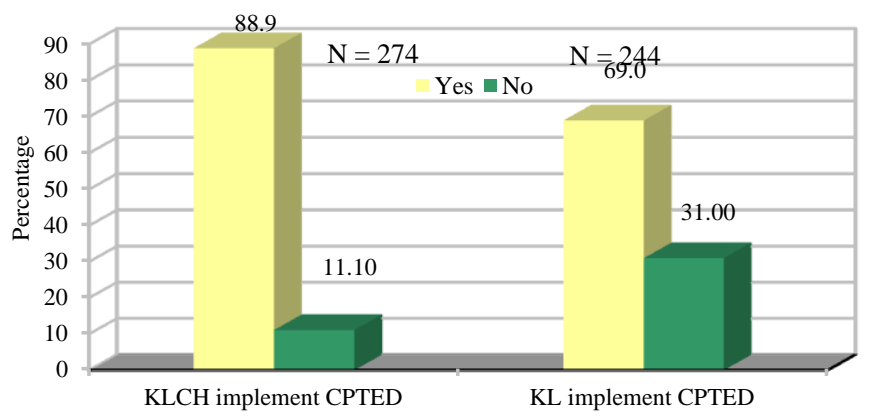

Figure 6.Awareness on CPTED implementation in Kuala Lumpur

Sources : Field Work, 2012

The relationship between both items, between the awareness of Safe City Implementation and CPTED Implementation was intended to strengthen the result and findings on the level of implementer's awareness. This is because the CPTED program is a more detailed program that outlines how the Safe City Program can be implemented. Hence, awareness of the Safe City Program will mean that the respondents will also be aware of CPTED. Both programs were implemented by the government simultaneously in the year 2004. By employing the correlation, it will increase the reliability and the validity of the findings and the result.

Data obtained show that the majority of implementers agrees that CPTED has been implemented by KLCH in Kuala Lumpur. The increment on awareness of CPTED implementation is reflected from the promotion by the JPPD since 2010 and yet in the year 2008 CPTED has become a policy in DKLCP 2020.

A significant correlation was observed between both awareness of CPTED implementation in Kuala Lumpur and CPTED implementation by 
Shuhana Shamsuddin \& Natasha Azim Hussin

Awareness by Kuala Lumpur City Hall Staffs for Successful Implementation of Crime Prevention through Environmental Design (CPTED)

$\mathrm{KLCH}, x^{2}=26.222^{\mathrm{a}}, \mathrm{p}<.05, \mathrm{p}=.000$. The finding shows that the value of $\mathrm{p}<$. 05 , with more than half of the implementers with 157 of them respond on the positive value of "yes" for both implementations. The Cramer V readings found that the awareness of CPTED implementation in Kuala Lumpur had a less significant relationship $(\mathrm{V}=0.335)$ to the CPTED implementation by the $\mathrm{KLCH}$.

Most of the implementers answered that the year of both program implementations were 2009 and 2010 and these represent the highest percentage rate in total. Promotion of Safe City and CPTED implementation was carried out on a large scale that began in 2009 after the government makes the crime prevention aspect as NKRA and become the focus in the GTP. In 2008 the Draft Kuala Lumpur City Plan 2020 has made CPTED as a policy to be followed and implemented. All these factors contributed to the awareness of both programs. Their awareness on both program implementations did improve where the momentum is picking up year by year starting from 2008 to 2010. If there is a higher level of awareness among implementers, they may diligently implement whatever instructions given by the organization. In addition to costs and benefits the nature of policy affects their knowledge base and level of the participant as implementers.

The implementer's post has a relationship on awareness as have been discovered in this study. The finding shows that the value of $\mathrm{p}<.05$, with majority of them comes from the subordinate's level with $67.8 \%$. As shown in Table 6.5, implementers post was significantly related to awareness on the CPTED implementation in Kuala Lumpur, $x^{2}=19.260^{\mathrm{a}}, \mathrm{p}<.05, \quad \mathrm{p}=.037$. Implementer's post had a less significant relationship $(\mathrm{V}=0.282)$ as a factor of successful implementation of CPTED.

Table I shows the percentage of officers who are aware of the actual implementation of CPTED by DBKL. Lack of promotion of the needs and interests in the implementation of CPTED affects the level of awareness of officers in KLCH. From the Fig. 5, it can be seen that the level of awareness began to rise after 2009 in which the government has embarked on the implementation of the Safe City program and massive CPTED implementation. The instruction on CPTED implementation in 2009 also comes with comprehensive CPTED guidelines in order to ensure that the implementers are conversant with the right method of CPTED implementation. 
PLANNING MALAYSIA:

Journal of the Malaysia Institute of Planners (2013)

Table 1: Percentage of awareness on CPTED implementation by KLCH

\begin{tabular}{lll}
\hline \hline Post & N & KLCH Officer \\
\hline Architect & 13 & $0 \%$ \\
Planner & 27 & $11 \%$ \\
Engineer & 17 & $17.6 \%$ \\
Building Surveyor & 7 & $28 \%$ \\
Admin Officer & 2 & $100 \%$ \\
Deputy Head of & 2 & $0 \%$ \\
Department & & \\
\hline \hline
\end{tabular}

The survey from qualitative data discovers that all officers are not aware of CPTED implementation but they are aware of the Safe City program. They assume that the Safe City program just started a few years back. A survey using an informal interview with other implements also found that all of them not aware and even never heard the CPTED term. The process of the successful implementation by the KLCH implements is disrupted when there is a loophole on awareness of CPTED. Without an awareness or knowledge of an issue, policy champions may find it difficult to further their cause as mention by [26] . As stated by [25] in his study of the attitudes of the implementing organization and staff, he discovered that the implementation of Citizen Charter in Upazila Land Office was unsuccessful due to the implementers not having sufficient knowledge about their Citizen Charter. It is important to put awareness of CPTED concept, knowledge and implementation of the implementers including top level management as a main factor in assuring a successful of CPTED. Followed by good communication, coordination and cooperation with all levels and having capable and skilled implementers with enough of resources and monitored regularly.

\section{CONCLUSION}

In conclusion, the data suggested that the level of awareness of $\mathrm{KLCH}$ implementers of CPTED implementation is low, less than 40\% in the year 2004. Their awareness started to rise up starting from the year 2008 as CPTED has become one of the policies in the Draft Kuala Lumpur City Plan 2020 and the percentage soared in 2010 due to the massive promotion of the Safe City program and CPTED. Despite the increase in the awareness of CPTED, the percentage on the level of awareness is still low at only 39\%. The lack of awareness on CPTED is due to the limited knowledge and poor understanding of CPTED concept and implementation, lack of promotion of the needs and interests in the implementation of CPTED. The level of awareness began to rise after 2009 in which the government has embarked on the implementation of the 
Shuhana Shamsuddin \& Natasha Azim Hussin

Awareness by Kuala Lumpur City Hall Staffs for Successful Implementation of Crime Prevention through Environmental Design (CPTED)

Safe City program that comes with comprehensive CPTED guidelines. A significant correlation was observed between both awareness of CPTED implementation in Kuala Lumpur and CPTED implementation by KLCH. Although the implements post was significantly related to the awareness of the CPTED implementation it had a less significant relationship as a factor of successful implementation of CPTED. The awareness of year of Safe City Implementation and year of CPTED implementation was significantly related although the relationship is not significantly strong

A conclusion made by the researchers is that the level of awareness of CPTED by KLCH implementers is still low. However the existence of unawareness and less successful implementation cannot be regarded as a failure of the implementers group only. As stated by [23] and [25] in which the organization and staffs are a key factor in the successful implementation award of a policy. The successfulness of CPTED implementation in Kuala Lumpur, a good collaboration between the administrative organizations and the implementers group in the KLCH are one of the main key factors in achieving a World Class City on the safety aspects. Evidence suggested that the impact and extent of CPTED is recently seen in terms of synergies between urban sustainability and CPTED [4]. It is claimed that the CPTED and other approaches may lead to the appearance of a 'sustainable urban environment' and a safer urban landscape that will create more liveable and healthy communities. As mentioned earlier, the CPTED strategies that are employed at the early stage of development would make it cheaper on the operational costs rather than be employed at later stages. It is the most costs effective for the tackling of crime in urban environment.

\section{ACKNOWLEDGMENT}

The support by Universiti Teknologi Malaysia for funding the research (vot 03J27), is gratefully acknowledged by the authors. Appreciation to Malaysia Federal Department of Town and Country Planning, Royal Malaysia Police for providing data and information for this research. A special thank you to the Kuala Lumpur City Hall for the scholarship awarded to the second author. 


\section{REFERENCES}

ACP Amar Singh Sidhu 2005, 'This Rise of Crime in Malaysia An Academic and Statistical Analysis', Journal of the Kuala Lumpur Royal Malaysia Police College, No. 4, p. 25, 23-24 March

Datuk Chor Chee Heung, 2010, Speech in "Towards Greater Cities and Better Living: Environmental Design for Crime Prevention", in Crime Prevention Through Environmental Design (CPTED) Seminar 2010

Glasson. John, Cozens. Paul, 2011, "Making communities safer from crime: An undervalued element in impact assessment", Environmental Impact Assessment Review 31 (2011) 25-35

Massoomeh Hedayati Marzbali, Aldrin Abdullah, Nordin Abd. Razak, Mohammad Javad Maghsoodi Tilaki, 2011, “A Review of the Effectiveness of Crime Prevention by Design Approaches towards Sustainable Development", Journal of Sustainable Development, Vol. 4, No. 1; February 2011

Erdal Gumus. 2004, Crime in Urban Areas: An Empirical Investigation, Akdeniz İ.İ.B.F. Dergisi (7), 98-109, Osmangazi Üniversitesi İ.İ.B.F. Maliye Bölümü, Öğretim Üyesi.

The World Bank, Latin America and Caribbean Region. 2008, Urban Crime and Violence in LAC: Status Report on Activities, International Bank for Reconstruction and Development / The World Bank

Cozens, P., 2007a. Planning, crime and urban sustainability. Sustainable Development and Planning III 1, 187e196.

Jabatan Perdana Menteri. 2011, Annual Report Government Transformation Programme Roadmap,. Unit Pengurusan Prestasi dan Pelaksanan (PEMANDU)

Crowe, Tim. 2000, Crime Prevention Through Environmental Design. 2nd edition. Boston: Butterworth - Heinman.

Massoomeh Hedayati Marzbali, Aldrin Abdullah, Nordin Abd. Razak, Mohammad Javad Maghsoodi Tilaki, 2012, Validating crime prevention through environmental design construct through checklist using structural equation modeling, International Journal of Law, Crime and Justice 40 (2012) 82e99,

Wong, T.C., Shaw, B. J., \& Goh, K. C. 2006. Challenging sustainability: Urban development and change in Southeast Asia (2nd ed.). California: Marshall Cavendish Academic.

Rebecca Lynn Wenzelm. 2007, CPTED: Interpreting Contemporary Security Practices In The Era Of Homeland Security, University of Texas

Robert A. Gardner. 1981, Crime Prevention Through Environmental Design, Security Management Magazine.

Matthew B. Robinson. 1996, The Theoretical Development Of CPTED 25 Years Of Responses To C. Ray Jeffery, Advances in Criminological Theory, Vol.8 (Edited by William Laufer and Freda Adler),

Lisa Jorgensen. 2007, Crime Prevention Through Environmental Design, , California State University, Sacramento, Vol. 63, No.3, Pg 26

Robinson, Matthew B. 1999, The Theoretical Development of 'CPTED': 25 Years of Responses to C. Ray Jeffery. Appears in: Advances in Criminological Theory, Vol. 8.

Ronald V. Clarke. 1998, The Theory Of Crime Prevention Through Environmental Design, School of Criminal Justice, Rutgers University, USA. 
Shuhana Shamsuddin \& Natasha Azim Hussin

Awareness by Kuala Lumpur City Hall Staffs for Successful Implementation of Crime Prevention through Environmental Design (CPTED)

Aldrin Abdullahb, Nordin Abd Razakb, Mohd Najib Mohd Sallehb \& Siti Rasidah Md Sakipa*, 2012Validating Crime Prevention through Environmental Design Using Structural Equation Model, AcE-Bs 2011 Bandung ASEAN Conference on Environment-Behaviour Studies, Savoy Homann Bidakara Bandung Hotel, Bandung, Indonesia, 15-17 June 2011, Procedia - Social and Behavioral Sciences 36 ( 2012 ) $591-601$

Malaysian Economic Planning Unit in the Malaysia $9^{\text {th }}$ Plan report (RMK 9)

Himilia Selamat., 2005, Aspek Keselamatan Jalan dan Kemudahan Pejalan Kaki di Pusat Bandar Dari Perspektif Wanita: Kajian Kes Jalan Tuanku Abdul Rahman Kuala Lumpur, Universiti Teknologi Malaysia.

Jamaludin Mustafa, 2007, Aspek Keselamatan Awam Dalam Pembentuk Bandar Selamat Di Malaysia: Kajian Kes Alor Setar, Kedah, Universiti Sains Malaysia

Chua Yan Piaw, 2006, Kaedah dan Statistik Penyelidikan: Kaedah Penyelidikan, Buku 1, McGRaw-Hill (Malaysia) Sdn. Bhd.

Anuphan Kitnitchiva, 2009, Major Factors Affecting The Implementation and Effectiveness of The R\&D Tax Incentive Policy, National Institute of Development Administration.

Creswell. J.W. and Clark V.L.P., 2007, Designing and Conducting Mixed Method Research, Sage Publication, Inc.

Zannatun Nayem, 2010, Problems of Implementing Citizan Charter: A Study of Upazila Land Office (A.C Land Office), North South University of Dhaka.

David Salvesen, Kelly R. Evenson, Daniel A. Rodriguez, and Austin Brown, 2008, Factors Influencing Implementation of Local Policies to Promote Physical Activity: A Case Study of Montgomery County, Maryland, J Public Health Management Practice, 2008, 14(3), 280-288

D. K. Bird, 2009, The use of questionnaires for acquiring information on public perception of natural hazards and risk mitigation - a review of current knowledge and practice, Published: 31 July 2009, Copernicus Publications on behalf of the European Geosciences Union.

Narendra Raj Paudel, 2009, A Critical Account of Policy Implementation Theories: Status and Reconsideration. Nepalese Journal of Public Policy and Governance, Vol. xxv, No.2. December 2009.pp 36-54.

Petrus A. Brynard. Policy Implementation: Lessons For Service Delivery. 27th AAPAM Annual Roundtable Conference. 5th - 9th December 2005. Livingstone, Zambia.

Rosalind Grace Namiiro Lubanga. 2010. Determining Policy Adequacy And Levels Of Implementation For The Attainment Of The Millennium Health Goals: The Case Of Malaria Control In Uganda. Doctor Philosophy. Makerere Universiti.

Leon M. Hermans. 2010. Ten Reasons Not To Monitor Policy Implementation, And What This Means To Evaluations, Faculty of Technology, Policy and Management. Delft University of Technology.

Halimaton Saadiah Hashim, Sarah Aziz, Rahimah Abdul Aziz. 2011. Conservation With Development:Showcasing Langkawi Geopark. Journal of the Malaysian Institute of Planner, Volume 9 Special Edition.2011.pp 1 - 24.

Saniah Ahmad Zaki \& Jamlunlaili Abdullah. 2012. The Relationship Between Variations Of Grid Layout And Burglary. Journal of the Malaysian Institute of Planner, Volume X.2012.pp $17-40$. 